Bond University

Research Repository

\title{
Fueling innovation through information technology in SMEs
}

Dibrell, Clay; Davis, Peter S.; Craig, Justin

Published in:

Journal of Small Business Management

DOI:

10.1111/j.1540-627X.2008.00240.x

Licence:

Other

Link to output in Bond University research repository.

Recommended citation(APA):

Dibrell, C., Davis, P. S., \& Craig, J. (2008). Fueling innovation through information technology in SMEs. Journal of Small Business Management, 46(2), 203-218. https://doi.org/10.1111/j.1540-627X.2008.00240.x

\footnotetext{
General rights

Copyright and moral rights for the publications made accessible in the public portal are retained by the authors and/or other copyright owners and it is a condition of accessing publications that users recognise and abide by the legal requirements associated with these rights.
}

For more information, or if you believe that this document breaches copyright, please contact the Bond University research repository coordinator. 


\section{Bond University}

\section{ePublications@bond}

$1-1-2008$

\section{Fueling innovation through information technology in SMEs}

Clay Dibrell

Oregon State University

Peter S. Davis

University of North Carolina at Charlotte

Justin B. Craig

Bond University, justin_craig@bond.edu.au

Follow this and additional works at: http://epublications.bond.edu.au/business_pubs

Part of the Entrepreneurial and Small Business Operations Commons, and the Technology and Innovation Commons

\section{Recommended Citation}

Clay Dibrell, Peter S. Davis, and Justin B. Craig. (2008) "Fueling innovation through information technology in SMEs" , .

http://epublications.bond.edu.au/business_pubs/86 
FUELING INNOVATION THROUGH INFORMATION TECHNOLOGY IN SMES

\author{
CLAY DIBRELL \\ COLLEGE OF BUSINESS \\ OREGON STATE UNIVERSITY
}

TEL: 541 737-4110

FAX: 541 737-4890

DIBRELLC@BUS.OREGONSTATE.EDU

\author{
PETER S. DAVIS \\ BELK COLLEGE OF BUSINESS \\ UNIVERSITY OF NORTH CAROLINA AT CHARLOTTE \\ CHARLOTTE, NC 28223. \\ TEL: 704.687.2062, \\ FAX: 704.687.3123 \\ PETER.DAVIS@UNCC.EDU.
}

\author{
JUSTIN B. CRAIG \\ SCHOOL OF BUSINESS, TECHNOLOGY AND SUSTAINABLE DEVELOPMENT \\ BOND UNIVERSITY \\ AUSTRALIA \\ TEL: 55951161 \\ FAX: 55951160 \\ jcraig@bond.edu.au
}

KEY WORDS: Innovation; Information Technology; SME

TOPIC OF RESEARCH: Small Business Technology and Innovation

The authors wish to thank Don Neubaum and the anonymous reviewers for their helpful comments and direction. Financial support was provided by the Austin Family Business Program in the College of Business at Oregon State University. 
CLAY DIBRELL is an Associate Professor of Strategic Management in the College of Business at Oregon State University. He earned his Ph.D. from The University of Memphis where he majored in Strategic Management and minored in International Business. Areas of research interest include a strong focus on strategic planning, the influence of information technology and temporal strategies on firm processes within the respective domestic, international, and entrepreneurial contexts. His research has been published in number of leading academic journals including the Journal of World Business, Management International Review, Family Business Review, and Industrial Marketing Management.

PETER S. DAVIS is a Professor of Management in Fogelman College of Business and Economics at The University of Memphis. He received his Ph.D. from the University of South Carolina. Articles by Dr. Davis have appeared in the Academy of Management Journal, Strategic Management Journal, Journal of International Business Studies, Management International Review, Journal of Business Research, Entrepreneurship Theory and Research, Journal of Small Business Management, and Family Business Review, among others.

JUSTIN CRAIG is an Assistant Professor of Entrepreneurship in the College of Business at Oregon State University. He earned his Ph.D. in Behavioral Science from Bond University in Australia. Areas of research interest include individual behavior and generational transitions in family-owned firms. His research has been published in Journal of Small Business and Enterprise Development, Journal of Management Development, Family Business Review, Journal of SEAANZ, and the Journal of Private Equity. 


\title{
FUELING INNOVATION THROUGH INFORMATION TECHNOLOGY IN SMES
}

\begin{abstract}
This paper describes a study that investigates the mediating effects of information technology (IT) on the relationships among product and process innovations and firm performance (measured in multiple profitability and growth rate metrics). Using structural equation modeling on a sample of 397 small- and medium-sized businesses (SMEs), we find evidence that (1) increases in the emphasis placed on innovation, both product and process, positively impacts the emphasis managers place on information technology; (2) the impact of innovation (both product and process) on performance (both profitability and growth) is primarily indirect, felt via the mechanism of the emphasis managers place on information technology; and (3) an increased emphasis on information technology abets managers’ perception of their firms' performance, as compared to that observed among peer firms (other SMEs).
\end{abstract}




\section{FUELING INNOVATION THROUGH INFORMATION TECHNOLOGY IN SMES}

A commitment to innovation has long been considered to be important to the success of entrepreneurial ventures and small firms (Fiol 1996). Research has shown that innovation stimulates ventures’ growth (e.g., Hax and Majluf 1991; Motwani, Dandridge, Jiang, and Soderquist 1999; Wolff and Pett 2006) and also provides a key source of competitive advantage in the absence of scale economies (Lewis, Welsh, Dehler, and Green 2002). Considered from the resource-based view of the firm (Barney 1991), successful innovation may be dependent on the presence of other organization-specific skills and capabilities. For example, substantial evidence has begun to accumulate that suggests that appropriate strategic employment of IT may be essential in translating strategies (e.g., innovation) into enhanced firm performance (e.g., Ray, Muhanna, and Barney 2005; Sakaguchi, Nicovich, and Dibrell 2004). A direct linkage between IT and firm performance was established by Powell and Dent-Micallef (1997). Bharadwaj (2000) found that high IT capable firms (those that invest heavily in IT) outperform competitors who do not invest to the same extent (also see, Sambamurthy, Bharadwaj, and Grover 2003). These results suggest IT offers firms a competitive competency, which aids firms in differentiating themselves in the marketplace, such as through innovation.

Despite their prominence as key constructs in the literature, possible relationships among innovation, IT, and performance have not been the subject of extensive investigation (Dewett and Jones 2001; Fichman 2001). It is generally acknowledged that the effective application of IT should enable firms to respond more appropriately to their environment (Das, Zahra, and Warkentin 1991), and receive and process information more efficiently (Hanson 1999; Perrow 1967), thereby facilitating competitive advantage (Barney 1991; Ray, Muhanna, and Barney 2005; Porter and Millar 1985). Consequently, firms often invest substantial resources in IT assets 
(e.g., computer hardware, computer software and personnel) (Krishnan and Sriram 2000). Over time, firms that invest more than their competitors in IT tend to realize greater returns from the marketplace (Bharadwaj 2000). However, there is not a substantial body of theory-driven empirical studies that demonstrate how innovation interacts with IT resources to enhance firm performance (for exceptions, see Croteau and Raymond 2004; Huang and Liu 2005;

Johannessen, Olaisen, and Olsen 1999; King and Burgess 2006). The purpose of the present study is to contribute to the closure of this gap. We achieve this by investigating further the potential benefits of IT, here presented as investments by the firm in both tangible and intangible assets, for innovation pursuant to enhanced firm performance.

Although prior studies have established evidence of beneficial performance and productivity impacts of IT investments (see for example, Bharadwaj, Bharadwaj, and Konsynski 1999; Bonk 1996; Huang and Liu 2005), there is also considerable skepticism to the benefits of IT and, consistent with what has become known as the "productivity paradox" (Trott and Hoecht 2004), IT investments do not meet performance objectives (e.g., Clegg et al. 1997) or that there is little or no relationship between IT investment and firm performance (e.g., Powell and DentMicallef 1997). Various arguments have been put forward as to why there is a lack of consensus in the value of IT investment. For example, Powell and Dent-Micallef (1997) suggest that IT is now so readily available and, as such, does not offer competitive performance. Others point to mis-measurement problems related to inputs and outputs (Wilcock and Lester 1997), confusion related to generalization of studies due to issues related to the level of analysis and the role of time lag effects between investment in technology and its payoff (Sangho and Kim 2006).

We acknowledge that while relationships among IT and strategic foci, such as innovation, and firm performance are the focus of considerable conjecture in various literatures (Johannessen 
et al. 1999; Sambamurthy, Bharadwaj, and Grover 2003) further and ongoing investigation of these relationships in the context of SMEs is warranted given the dramatic advancement of IT that has shifted SMEs to more advantageous positions in organizational flexibility and efficiency terms (Izushi 2003; Larsen and Lomi 2002; Tanabe 2005; Xiang and Lan 2001). In particular, Cooper (1998) highlights that due to advances in computer technology, the declining cost of systems and improved software and technological sophistication of the workforce, no longer are adaptations reserved for the technologically elite, which results in opportunities for innovation in the small firm. Further support for our examination of IT and innovation relationships is drawn from Dewett and Jones (2001:326) who stress that, "because IT moderates many aspects of the process of bringing new problem-solving ideas into use given that it determines the way information is stored, transmitted, communicated, processed and acted upon, IT is an important but neglected means of facilitating the innovation process.”

Our study provides distinguishing contributions to the extant literature in the following ways. First, while previous studies often collapsed product and process innovations into a single variable, we separate product innovation from process innovation in our analyses to be consistent with indications in the literature that each form of innovation would have differing impacts on performance outcomes (c.f., Olson, Slater, Hult 2005; Vermeulen 2005; Wolff and Pett 2006). A second distinguishing contribution of the current study from prior studies is that we broaden the measurement of firm performance to include multiple profitability and growth rate metrics. Third, a compelling characteristic of the study is its context. While some studies have investigated the impact of information technology or innovation on performance, to date, there have been relatively few empirical studies that have demonstrated this association among the vast population of small and medium-sized enterprises (Huang and Liu 2005). 
The paper is organized into four sections. The first section draws upon strategic management and management information systems literatures to describe the critical components of innovation and IT, and presents theory-driven links among IT, innovation and firm performance. From this, we distill our hypotheses and present our conceptual framework. The second and third sections consist of methods and results respectively. Lastly, the discussion and conclusion section elaborates on the findings of this study.

\section{LITERATURE REVIEW}

\section{Innovation}

Innovations vary in complexity and can range from minor changes to existing products, processes or services to breakthrough products, and processes or services that introduce firsttime features or exceptional performance. Process definition of innovation proponents concern themselves mainly with how the interplay between events and people at each stage of the process influences events in subsequent stages, determining whether the adoption process will continue or not (Cooper 1998). Issues of interest for these scholars include the role of communication in facilitating successful innovation, best practices in terms of sequencing the stages of innovation, the characteristics of individuals and teams in successful and unsuccessful processes, and the nature of the relationships between parties involved in the innovation process (Frishammar and Hörte 2005). In contrast, those who see innovation as a discrete event suggest that implementation of innovation occurs when there is actual acceptance of risk and the commitment of resources occurs. A growing number of practitioners and researchers define innovation as any idea, practice, or object that the adopting individual or organization regards as new (e.g., Bhaskaran 2006; Damanpour 1991). From this perspective, the newness attached to an 
innovation remains a matter of perception. Innovation has further been defined as "the willingness to place strong emphasis on research and development, new products, new services, improved product lines, and general technological improvement in the industry” (Slevin and Covin 1990: 43). Regardless of definitional debates, success in innovation typically requires strong managerial support and resource commitment (Fujita 1997). Even then, only 4\% of all new product innovations beat the expected return on investment (Nussbaum, Berner, and Brady 2005).

Examinations of innovation have been divided into two major research streams (Brown and Eisenhardt 1998). The first stream examines issues related to the diffusion of innovations across nations, industries, and organizations (e.g., O'Neill, Pouder, and Buchholtz 1998). In this stream, an innovation is defined as a technology, strategy, or management practice that a firm is using for the first time, whether or not other organizations or users have previously adopted it, or as a significant restructuring or improvement in a process (O'Neill et al. 1998). The second stream examines the influence of organizational structures, strategic processes, and people on the development and marketing of new products (e.g., Zahra 1993; Zirger and Maidique 1990). Within this second research stream, an innovation refers to a new product that an organization has created for the market and represents the commercialization of an invention, where invention is an act of insight (Damanpour 1991). New products may take different forms, such as upgrades, modifications, and extensions of existing products.

The most prominent innovation dimensions within these research streams are radical, incremental, product, process, administrative and technological (Camison-Zomoza et al. 2004). The two most common of these innovation dimensions are product innovation and process innovation (Daft 2001). Broadly, product innovation reflects change in the end product or service 
offered by the organization, while process innovation represents changes in the way firms produce end products or services (Camison-Zomoza et al. 2004). Both product and process innovation have been shown to be potentially significant sources of strategic advantage. Process innovation historically seems to favor large firms operating in mature markets with high organizational slack, is efficiency focused and, as such, is centered on lowering a firm's average cost of production (Garcia and Calantone 2002). Process innovation, in this research, refers to the changes made in the processes or technologies used by the organization to deliver products or services, while product innovations are defined in this research as new products or services introduced to meet an external user or market need (Walker 2005).

\section{IT Investment}

With IT’s increasing sophistication and usage, managers now consider the use of IT as a competitive tool used for the implementation of strategic plans and the support of firm core competencies (e.g., Dibrell and Miller 2002; Gibbons and O’Connor 2003). As a consequence, investment in IT by firms has dramatically escalated in recent times (Devaraj and Kohli 2003; Tippins and Soh 2003). IT can be used to influence a firm's ability to gain a competitive advantage (e.g., Kohli and Devaraj 2003; Ravichandran and Lertwongsatien 2005) through the linkage of IT with a firm's strategy and industry. Das, Zahra, and Warkentin (1991) suggest that linking strategy to IT allows firms to compete more effectively. A study by Powell and DentMicallef (1997) confirmed a direct link between IT and firm performance. Ravichandran and Lertwongsatien (2005) also found a direct relationship between investments in IT capabilities and firm financial performance. However, since prior studies focused on the population of large, often diversified companies, questions remain as to whether these results are generalizable to 
SMEs. Supposedly, the more flexible managerial capabilities of SMEs dictate the extent of success of IT adoption and the resulting positive effects on financial performance (Khazanchi 2005). In this event, smaller firms should be able to more effectively utilize IT to exploit newer technologies than their larger, less agile competitors (Bonk 1996; Xiang and Lan 2001).

\section{IT Investment, Innovation and Firm Performance}

Firm performance is enhanced when there are synergies among the elements of a system. Complementary factors of a system of mutually enhancing elements operate in such a way that doing more of one thing increases the returns of doing more of another (Huang and Liu 2005). As such, investment in IT does not stimulate productivity and growth (i.e., firm performance) without a number of complementary developments and, even then, resource commitment in IT may detract from short-run profitability (Johannssen et al. 1999). Innovation also exists with the same characteristic, that is, focusing on innovation is likely to influence organizational structures and systems (Craig, Cassar and Moores 2006). For example, as innovation entails considerable risk taking (Blumentritt and Danis 2006), successful implementation requires making significant systemic changes in a firm to promote risk. A strategy that focuses on innovation will also likely require some degree of flexibility in its organizational structure (Blumentritt and Danis 2006). Open channels of communication, decentralization and informal decision making, loosely coupled decision linkages and loosely identified job descriptions, and flexibility in processes and procedures are all associated with innovative activity (Mintzberg 1979). For an organization to develop the capacity for sustained innovation, as well as incorporating innovation as a meaningful component of strategy, it must make resources available for new products and provide collaborative structures and processes to solve problems creatively and connect 
innovations with existing businesses (Bhaskaran 2006). IT is seen as vital to building this capacity (King and Burgess 2006). Firm performance is enhanced, therefore, when innovative activity is complemented by IT initiatives that result in the systematic introduction of new processes and products that fit with existing processes, promoting increased customer loyalty, and stimulating demand for other products (Frishammar and Hörte 2005).

\section{HYPOTHESES}

SMEs that can demonstrate timely responsiveness and rapid and flexible product innovation, coupled with the management capability to effectively coordinate and redeploy internal and external competences can potentially build a competitive advantage (Tanabe and Watanbe 2005; Teece, Pisano, and Shuen 2000; Zahra, Neubaum and Laranetta, forthcoming). Such efforts largely overlook what has rapidly become a fundamental and crucial firm operation, information technology. Dewett and Jones (2001) have extended the IT to performance proposition by stressing the need to incorporate firm-level strategy into this body of research. Through their theoretical examination, the authors argue that IT directly influences the strategy to firm performance relationship. Moreover, Lee and Runge (2001), in their study of SMEs, found that firms which are innovative are more likely to employ IT successfully. These innovative firms are also more likely to realize greater value from IT than firms that are less innovative. Based on this logic, we propose the following hypothesis:

Hypothesis 1: An emphasis on innovation will be positively associated with an emphasis on information technology in small- and medium-sized firms.

Despite the fact that the majority of innovations come from the small business sector (SBA 2004), empirical innovation research has tended to focus on large publicly-held organizations (Gudmundson et al. 2003; Verhees and Meulenberg 2004). SMEs are increasingly 
being recognized for their innovativeness through new product and process developments (Freel 2003). Innovation in small firms is different to large firms (Audretsch 2001; Eden, Levitas, and Martinez 1997) and these firms are able to respond to changes in demand through their organizational flexibility. Further, due to their close relationships to customers, small firms can detect market niches more efficiently and effectively than larger firms. Brown and Blackmon (2005) suggest that smaller firms can combine the flexibility of production organization with product specialization, creating a way out of the constraints of mass production. Comparably, Ojha (2004) argues that larger long-stable organizations are especially challenged by changes in technology. These previous studies lead to our second hypothesis:

Hypothesis 2: An emphasis on innovation will be positively associated with financial performance in small- and medium-sized firms.

Prior works, for the most part, ignore the processes involved in the use of IT as a means of generating greater profitability (Bharadwaj 2000; Dewett and Jones 2001) and only investigate the direct linkage of IT to firm performance (for exceptions see, Huang and Liu 2005; Verhees and Meulenberg 2004). This point is especially poignant when considering SMEs. In reviewing the SME IT research, Khazanchi (2005) emphasizes the necessity to study additional organizational variables when considering the role of IT on firm performance. Likewise, he indicates that IT should have a demonstrable and positive effect on firm performance when other organizational constructs are considered. Consequently, when a firm actively engages in an innovation strategy, we hypothesize that IT will have a positive relationship to firm performance:

Hypothesis 3: In the presence of a firm strategy of innovation, an emphasis on information technology will be positively associated with financial performance in small- and medium-sized firms.

The conceptual model presented in Figure 1 provides a summary of the relationships that are under investigation in this research. 


\section{METHODOLOGY}

\section{Sample}

Following Salant and Dillman’s (1994) recommendation for conducting survey studies, 2200 potential respondents were selected from a Dun \& Bradstreet mail list of the population of firms residing in a state within the United States that met our criteria of being for profit SMEs (i.e., 6 to 499 employees) with the key respondent (owner, CEO, director) in a knowledgeable management position (Floyd and Wooldridge 1994). 351 respondents asked to be removed from our mailing list resulting in an effective sample pool of 1849, which produced our final sample size of 375 and a response rate of 20.3\%. This response rate compares more favorably than other studies which have targeted top management team members (Hambrick, Gelekanycz, and Fredrickson 1993).

The industry sample break down is: Agriculture, Forestry, Hunting, Fishing (n=47); Manufacturing (n=95); Finance, Insurance, Real Estate (n=14); Health, Education, Social Services ( $n=23)$; Mining, Construction ( $n=72)$; Transportation, Communication, Utilities ( $n=26)$; Retail, Hotel, Restaurant ( $n=45)$; Business Services $(n=58)$; and Consumer Services ( $n=17)$. The age of the firms ranged from 1 to greater than forty years with the median range of the sampled firms from 20-29 years. The median size of the firms was in the 20 to 49 employee category with a small minority of firms larger than 100 employees $(n=18)$. We tested for potentially confounding effects associated with cross-industrial surveys and found no statistically significant differences on the demographics of industry life cycle and firm age. Though our response rate 
was high, non-response bias could still obfuscate our findings. As suggested by Armstrong and Overton (1977), a t-test on the studied constructs between early vs. late respondents was conducted, and no statistical differences were revealed.

Given the potential rural location specific bias associated with some of the natural resource based industries in our sample (e.g., mining, agriculture), we tested for potential confounding effects associated with a location specific bias by classifying locations as rural which had less than 50,000 residents and urban, greater than 50,000 residents. These results suggest that there are no differences between rural vs. urban on the studied dimensions. This finding extends the generalizability of our findings to include not only SMEs in rural areas but also urban areas. Likewise, these findings further strengthen support for our earlier finding concerning non-response bias, as firms regardless of geographical location, demographics, and industry-classification answered comparably.

Similarly, we were concerned about the potential effects associated with common method bias. To check for the effects associated with common method bias, we conducted a principal component analysis of all the items employed in the study (Harman 1967; Podsakoff and Organ 1986). Four factors emerged with Eigen values greater than 1, with the first factor accounting for only $34 \%$ of the explained variance indicating that common method bias should not influence the results.

To test for effects of multi-collinearity, which may be a result of common method variance, we conducted a multiple regression analysis with the three criterion variables (product innovation, process innovation, and IT investment) regressed on the dependent variable of firm performance. The variance inflation factor (VIF) scores for the three measures were below 1.5, which is much lower than the VIF cutoff of 10 (Chatterjee and Price 1991). 
Innovation. As product and process innovations have different performance impacts (Olson, Slater, and Hult 2005), we employed separate scales to examine product innovation and process innovation.

Product Innovation. To tap product innovation, we used a three-item scale developed by Miller and Friesen (1982), which has been used extensively in the literature. The three items captured the extent of product innovation within a firm. Respondents were asked to compare their firm to other firms in their respective industries. The items were: (1) "there exists a very strong emphasis on marketing of tried and true product/services" compared to "there exists a very strong emphasis on R\&D, technological leadership, and innovations;" (2) "no new lines of products, services, or programs were introduced during the past three years" versus "more than half of our product lines or services were introduced during the past three years;” and (3) "changes in product lines have been minor over the last three years" opposed to "changes in product lines have been major over the last three years.”

Process Innovation. To assess a firm's emphasis on process innovation, we adapted items assessing process innovation from Dess and Davis (1984) and Davis, Dibrell, and Janz (2002). Respondents were asked to answer four questions with the anchors " $1=$ not at all" to " 5 = great extent" in relation to the emphasis that their firm places on specific process-related innovation activities. The four items were (1) innovation in production processes; (2) investing in new R\&D facilities to gain a competitive advantage; (3) producing specialty products; and (4) higher production efficiency than competitors.

IT Asset Investment. Management information systems scholars (e.g., Mahmood and Mann 1993; Sakaguchi and Dibrell 1998) suggest that an appropriate way to gauge a firm’s emphasis on IT is to look at their investments in IT assets (e.g., hardware, software, and 
personnel) relative to other competitors within the same industry. Drawing upon a scale developed and validated by Sakaguchi and Dibrell (1998), we modified their scale to a four item scale which included respondents being asked to report their (1) total dollar value of IT assets;

(2) total IT investment; (3) number of IT employees; and (4) number of personal computers and terminals per employee.

Firm Performance. The firms participating in this study were SMEs that were not publicly traded. Like many of the study’s constructs, measuring performance required data that were unavailable from suitable secondary data sources. Hence, we used subjective measures of performance provided by the respondent managers to capture firms’ relative profitability and growth as compared to that of their peer competitors (other SMEs). Following Dess and Robinson (1984) and Davis et al. (2002), managers were asked to report their primary business unit's return on assets, return on sales, sales growth, and market share growth.

\section{Analyses}

Structural equation modeling using LISREL 8.52 was employed for validation of the scales through confirmatory factor analysis and for hypothesis testing. This statistical analysis was chosen as both the measurement and structural models are estimated simultaneously (e.g., Jöreskog 1978).

\section{RESULTS}

As seen in Table 1, the coefficient alphas ranged from a low of .69 for a process innovation strategy to a high of .88 for IT asset investment and firm financial performance. The correlation matrix indicated that multicollinearity did not seem to be present in the sample. 
For construct validation, a two-phase confirmatory factor analysis approach was conducted, as suggested by Anderson and Gerbing (1988). First, the reflective measures were tested. The standardized factors loadings were above .50 and were statistically significant ( $p<$ .05). Second, a series of sequential chi-square models were compared, specifically, the null one factor model, the constrained four factor model (the latent constructs were not allowed to correlate), and the unconstrained four factor model (the latent constructs were allowed to correlate). The unconstrained factor model demonstrated the best fit among the three models with the following results $(\chi 2=264.69$; d.f. $=84, p<.05$; comparative fit index (CFI: Bentler 1990 $)=.95 ;$ Delta2 $($ Bollen 1989) $=.95$; relative noncentrality index $($ RNI: McDonald and Marsh 1990) $=.95$; and the root mean square error of approximation (RMSEA: Steiger and Lind 1980) RMSEA $=.083$; and the goodness of fit index $(\mathrm{GFI})=.90$. These results indicate that the constructs in the measurement model demonstrate convergent and discriminant validities.

With the scales validated, we proceeded to test the hypothesized model. The model fits the data strongly $(\chi 2=123.40$, d.f. $=81, p<0.05 ; \mathrm{CFI}=.99$; Delta2 $=.99 ; \mathrm{RNI}=.99$; $\mathrm{RMSEA}=$ .04 ; and GFI $=.95)$, as shown in Table 2. Hypothesis $1 \mathrm{a}(\beta=.27 ; p<.05)$ and Hypothesis $1 \mathrm{~b}(\beta$ $=.20 ; p<.05$ ) were both supported. The squared multiple correlation (comparable to $\mathrm{R}^{2}$ in regression analysis) for this equation was .11, suggesting that $11 \%$ of the variation associated with information technology can be explained through product and process innovations. For Hypothesis 2, product innovation to (a) performance $(\beta=.02 ; p>.05)$ and process innovation to (b) performance ( $\beta=.04 ; p>.05)$ were rejected. In Hypothesis 3 , information technology did have a positive path to firm performance $(\beta=.59 ; p<.05)$, resulting in support for this hypothesis. Further, 37\% of firm performance variation (the squared multiple correlation for 
performance) was explained mainly through information technology with a smaller percentage explained by product and process innovations.

Insert Table 2 Here

\section{DISCUSSION AND CONCLUSION}

The findings of this study extend the SME, information technology, and innovation literatures and help build a foundation for further understanding the link between innovation and information technology and performance outcomes. From the results, we are able to make multiple observations. First, the impact of innovation (both product and process) on performance (both profitability and growth) is primarily indirect and is instead fueled by information technology. The initiatives of innovation and information technology are complementary. In order to optimize investment in innovation activities, information technology initiatives should be aligned with innovation. Second, SMEs that compete with larger firms are able to level the competitive playing field by utilizing information technology. Further, SMEs should consider how they apply information technology to other strategic initiatives, such as customer responsiveness, in order to enhance overall effectiveness of the strategy.

The extant literature on innovation reveals that through investment in product and process innovations, firms expand their core capabilities in the areas of products, knowledge, and skills. Because investing in capabilities like these yield competitive advantage, the resultant distribution of such capabilities will tend to give certain firms an advantage relative to others (Barney 1991; Ray, Muhanna, and Barney 2005). Our results support that the potential for developing innovative capabilities may not need to be closely related to particular products to yield benefits. The finding that process innovation abets performance, albeit indirectly, suggests that it may be 
in the firm's best interests to invest in innovative capabilities, even when the innovation is not directly tied to a specific product.

The development of a range of innovative capabilities, whether in the form of products or processes, may offer the firm a set of strategic choices that can be exercised if customers' expectations fail to materialize or should shift suddenly (Amram and Kulatilaka 1999; Bowman and Hurray 1993). In contrast, it appears that a failure by SMEs to invest in innovation makes them slower to acquire necessary innovative capabilities than other SMEs, and thus less able to respond to changing technological and competitive market expectations and opportunities. Being an innovator in a fast moving market may confer advantages associated with technological leadership and first mover advantages (Christensen 1998). A failure to invest in one or the other form of innovation, either product or process, may cause an SME to be unable to respond effectively to competitors' introduction of new products or process enhancements. An SME that fails to continually invest in innovation places itself at greater risk of having products and services marginalized by technologically superior competitors.

With regards to IT, in many respects, our findings appear to support contentions by Ravichandran and Lertwongsatien (2005) that an SME which is able to understand the power of IT, and to link this power to support the core competencies of the firm successfully, can have a competitive advantage. From our results, it appears that managers who are able to integrate either a product or a process-oriented innovation strategy with investments in IT enhance their firms' relative performance along two essential dimensions: profitability and growth. In contrast, a failure to invest in IT can cause a firm to be unable to support its innovation initiatives. Perhaps, a lack of investment in IT over time may render the firm incapable of meeting customer requirements. 
For performance, our study demonstrates that IT does have a positive and significant effect on current profitability and future growth. We posit that this is due to an increase in managerial sophistication of IT usage and the increased production capacity of IT. Likewise, managers have increased their knowledge and understanding of the most effective ways to implement their firm's strategies with IT. Our reasoning once again suggests that firms are able to create unique resources and capabilities through the use of IT that are not easily inimitable, consistent with the resource-based view.

As with any research, associated with our study are limitations that offer opportunities for future research. With only one key respondent per firm, respondents could have a skewed perspective of the different model components, which future researchers may wish to triangulate with other respondents from the same firm or from external observers. In addition, despite previous research showing a strong correlation between objective and perceptual measures (Dess and Robinson 1984; Jennings and Young 1990), future research may wish to examine alternative measures as well address questions attendant to common method variance. Finally, our findings may extend beyond the relationship demonstrated between innovation and IT to other types of SME orientations and behaviors, such possibilities are certainly worthy of further investigations.

Finally, we note several managerial implications for SMEs. Recall the three key findings that emerged: (1) that product and process innovations exhibited strong linkages with IT; (2) IT mediated the innovation to firm performance direct relationship; and (3) IT was positively related to performance. Based on these findings, managers should be more willing to invest in IT; however, managers must also be cognizant of the necessity to create systems and processes that most effectively optimize IT usage. Our study, in conjunction with past research, clearly 
demonstrates the need for a firm to invest in IT and to hire employees that are capable of utilizing IT to implement competitive business level strategies successfully. 


\section{REFERENCES}

Amram, M., and N. Kulatilaka (1999). Real Options. Boston: Harvard Business School Press.

Anderson, J. C., and D. W. Gerbing (1988). "Structural Equation Modeling in Practice: A

Review and Recommended Two-step Approach,” Psychological Bulletin 103, 411-423.

Armstrong, S., and T. S. Overton (1977). "Estimating Non-response Bias in Mail Surveys,” Journal of Marketing Research 14, 396-402.

Audretsch, D. B. (2001). "Research Issues Relating to Structure, Competition, and Performance of Small Technology-Based Firms,” Small Business Economics 16(1), 37-51.

Barney, J. (1991). “Firm Resources and Sustained Competitive Advantage,” Journal of Management 17, 99-120.

Bentler, P. M. (1990). “Comparative Fit Indexes in Structural Equation Modeling,” Psychological Bulletin 107 (2), 238-46.

Bharadwaj, A. S. (2000). “A Resource-based Perspective on Information Technology Capability and Firm Performance: An Empirical Investigation,” MIS Quarterly 24, 169-196.

Bharadwaj, A, Bharadwaj, S. and B. Konsynski (1999). "Information Technology Effects on Firm Performance as Measured by Tobin’s Q,” Management Science 45(7), 1008-1024.

Bhaskaran, S. (2006). "Incremental Innovation and Business Performance: Small and MediumSize Food Enterprises in a Concentrated Industry Environment,” Journal of Small Business Management 44(1), 64-80.

Blumentritt, T, and W. M. Danis (2006). "Business Strategy Types and Innovative Practices,” Journal of Managerial Issues, 18, 274-291.

Bollen, K. A. (1989). Structural Equations with Latent Variables. New York: John Wiley \& Sons. 
Bonk, E. T. (1996). “The Information Revolution and its Impact on SME Strategy: The Asia Pacific Economic Cooperative Forum as a Model,” Journal of Small Business Management 34(1), 71-77.

Bowman, E., and D. Hurry (1993). "Strategy Through the Option Lens: An Integrated View of Resource Investments and the Incremental-Choice Process,” Academy of Management Review 18, 760-782.

Brown, S., and K. Blackmon (2005), “Aligning Manufacturing Strategy and Business-Level Competitive Strategy in New Competitive Environments: The Case for Strategic Resonance,” Journal of Management Studies, 42, 793-815.

Brown, S. L., and K. M. Eisenhardt (1998). Competing on the Edge: Strategy as Structured Chaos. Boston: Harvard Business School Press.

Camison-Zomoza, C., R. Lapiedra-Alcamí, M. Segarra-Cipres, M. Boronat-Navarro (2004). “A Meta-analysis of Innovation and Organizational Size,” Organization Studies, 25, 331361.

Chatterjee, S. and B. Price (1991). Regression Diagnostics. New York: John Wiley \& Sons. Christensen, C. M. (1998). “Strategies for Survival in Fast-Changing Industries,” Management Science 44, 207-221.

Clegg, C., C. Axtell, L. Damodaran, B. Farbey, R. Hull, R. Lloyd-Jones, R. Sell and C. Tomlinson (1997). “Information Technology: A Study of Performance and the Role of Human and Organizational Factors,” Ergonomics 40(2), 851-871.

Cooper, J. (1998). “A Multidimensional Approach to the Adoption of Innovation,” Management Decision 36(8), 493-502. 
Craig, J. B., G. Cassar, and K. Moores (2006). “A Ten Year Investigation of Strategy, Systems and Environment upon Innovation in Family Firms,” Family Business Review 19(1), 110.

Croteau, A. M., and L. Raymond (2004). "Performance Outcomes of Strategic and IT Competencies Alignment,” Journal of Information Technology 19(3), 178-190.

Daft, R. L. (2001). Organization Theory and Design, 7th ed. Cincinnati, Ohio: South Western College Publishing.

Damanpour, F. (1991). “Organizational Innovation: A Meta-Analysis of Effects of Determinants and Moderators”, Academy of Management Journal 34, 555-90.

Das, S. R., S. A. Zahra, and M. E. Warkentin (1991). "Integrating the Content and Process of Strategic MIS Planning with Competitive Strategy,” Decision Sciences 22, 953-984.

Davis, P. S., C. C. Dibrell, and B. Janz (2002). “The Impact of Time on the StrategyPerformance Relationship: Implications for Managers,” Industrial Marketing Management 31(4), 339-347.

Dess, G. G., and P. S. Davis (1984). ”Porter's (1980) Generic Strategies as Determinants of Strategic Group Membership and Organizational Performance,” Academy of Management Journal 27, 467-488.

Dess, G. G., and R. B. Robinson (1984). ”Measuring Organizational Performance in the Absence of Objective Measures: The Case of the Privately-Held Firm and Conglomerate Business Unit,” Strategic Management Journal 5, 263-272.

Devaraj, S., and R. Kohli (2003). "Performance Impacts of Information Technology: Is Actual Usage the Missing Link?” Management Science 49(3): 273-289. 
Dewett, T., and G. R. Jones (2001). “The Role of Information Technology in the Organization: A Review, Model, and Assessment,” Journal of Management 27, 313-346.

Dibrell, C., and T. Miller (2002). “Organization Design: The Continuing Influence of Information Technology,” Management Decision 40(6), 620-627.

Eden, L., E. Levitas, and R. J. Martinez (1997). “The Production, Transfer, and Spillover of Technology: Comparing Large and Small Multinationals as Technology Producers,” Small Business Economics 9(1), 53-66.

Fichman, R. G. (2001). “The Role of Aggregation in the Measurement of IT-Related Organizational Innovation,” MIS Quarterly 25(4), 427-455.

Fiol, C. M. (1996). “Squeezing Harder Doesn't Always Work: Continuing the Search for Consistency in Innovation Research,” Academy of Management Review 21, 1012-1021.

Floyd, S. W., and B. Wooldridge (1994). “Dinosaurs or Dynamos? Recognizing Middle Management’s Strategic Role,” The Academy of Management Executive 8(4), 47-57.

Freel, M. S. (2003). “Sectoral Patterns of Small Firm Innovation, Networking and Proximity,” Research Policy 32(3), 751-770.

Frishammar, J., and S. A. Hörte (2005). “Managing External Information in Manufacturing Firms: The Impact on Innovation Performance,” Journal of Product Innovation Management 22, 251-266.

Fujita, S. (1997). A Strategy for Corporate Innovation. Tokyo: Asian Productivity Organization. Garcia, R., and R. Calantone (2002). “A Critical Look at Technological Innovation Typology and Innovativeness Terminology: A Literature Review,” The Journal of Product Innovation Management 19, 110-132. 
Gibbons, P. T., and T. O’Connor (2003). “Strategic Posture, Technology Strategy and Performance Among Small Firms,” Journal of Enterprising Culture 11(2), 131-146.

Gudmundson, D., C. Burk Tower, and E. A. Hartman (2003). "Innovation in Small Businesses: Culture and Ownership Structure do Matter,” Journal of Developmental Entrepreneurship 8(1), 1-17.

Hambrick, D. C., M. A. Gelekanycz, and J. W. Fredrickson (1993). ”Top Executive Commitment to the Status Quo: Some Tests of Determinants," Strategic Management Journal 14, 401-417.

Hanson, M. T. (1999). “The Search-Transfer Problem: The Role of Weak Ties in Sharing Knowledge Across Organizational Subunits,” Administrative Science Quarterly 44, 82111.

Harman, H. (1967). Modern Factor Analysis. Chicago: University of Chicago Press.

Hax, A., and N. Majluf (1991). The Strategy Concept and Process. Englewood Cliffs, NJ: Prentice Hall.

Huang, C. J. and C. J. Liu (2005). “Exploration for the Relationship between Innovation, IT, and Performance,” Journal of Intellectual Capital 6(2), 237-252.

Izushi, H. (2003). "Impacts of the Length of Relationships upon the Use of Research Institutes by SMEs,” Research Policy 32(3), 771-788.

Jennings, D. F., and D. M. Young (1990). “An Empirical Comparison between Objective and Subjective Measures of the Product Innovation Domain of Corporate Entrepreneurship,” Entrepreneurship Theory and Practice 15, 53-66. 
Johannessen, J. A., J. Olaisen, and B. Olsen (1999). “Strategic Use of Information Technology for Increased Innovation and Performance," Information Management and Computer Security 7(1), 5-22.

Jöreskog, K. G. (1978). “Structural Analysis of Covariance and Correlation Matrices,” Psychometrika 43, 443-477.

Khazanchi, D (2005). “Information Technology (IT) Appropriateness: The Contingency Theory of 'Fit' and IT Implementation in Small and Medium Enterprises," Journal of Computer Information Systems 45(3), 88-95.

King, S. F., and T. F. Burgess (2006). "Beyond Critical Success Factors: A Dynamic Model of Enterprise System Innovation,” International Journal of Information Management 26, 59-69.

Kohli, R., and S. Devaraj (2003). "Measuring Information Technology Payoff: A Meta-Analysis of Structural Variables in Firm-Level Empirical Research,” Information Systems Research 14(2), 127-145.

Krishnan, G. V., and R. S. Sriram (2000). “An Examination of the Effect of IT Investments on Firm Value: The Case of Y2K-Compliance Costs,” Journal of Information Systems 14, 95-108.

Larsen, E., and A. Lomi (2002). “Representing Change: A System Model of Organizational Inertia and Capabilities as Dynamic Accumulation Processes,” Simulation Modeling Practice and Theory 10, 271-296.

Lee, S., and J. Runge (2001). “Adoption of Information Technology in Small Business: Testing Drivers of Adoption for Entrepreneurs,” Journal of Computer Information Systems 42(1), 44-57. 
Lewis, M. W., M. A. Welsh, G. E. Dehler, and S. G. Green (2002). “Product Development Tensions: Exploring Contrasting Styles of Project Management,” Academy of Management Journal 45(3), 546-564.

Mahmood, M. A., and G. J. Mann (1993). "Measuring the Organizational Impact of Information Technology Investment: An Exploratory Study,” Journal of Management Information Systems 10, 97-122.

McDonald, R., and H. Marsh (1990). “Choosing a Multivariate Model: Noncentrality and Goodness of Fit,” Psychological Bulletin 107 (2), 247-55.

Miller, D., and D. Friesen (1982). “Innovation in Conservative and Entrepreneurial Firms: Strategic Momentum,” Strategic Management Journal 3, 1-25.

Mintzberg, H. (1979). Structuring of Organizations. Englewood Cliffs, NJ: Prentice-Hall.

Motwani, J., T. Dandridge, J. Jiang, and K. Soderquist (1999). “Managing Innovation in French Small and Medium-Sized Enterprises,” Journal of Small Business Management 37(2), 106114.

Nussbaum, B., R. Berner, and D. Brady (2005), “Get Creative,” Business Week, Is. 3945, 60-68. Ojha, A. K. (2004), “Organizational Forms in the Electronic Age,” The Journal for Decision Makers, 29, 83-95.

Olson, E. M., S. F. Slater, and G. T. M. Hult (2005), “The Performance Implications of Fit Among Business Strategy, Marketing Organization Structure, and Strategic Behavior,” Journal of Marketing, 69, 49-65.

O'Neill, H. M., R. W. Pouder, and A. K. Buchholtz (1998). "Patterns of Diffusion of Strategies across Organizations: Insights from the Innovation Diffusion Literature,” Academy of Management Review 23, 98-114. 
Piore, M., and C. Sabel (1984). The Second Industrial Divide. New York: Basic Books.

Perrow, C. (1967). “A Framework for the Comparative Analysis of Organizations,” American Sociological Review 32, 194-208.

Podsakoff, P. M., and Organ, D. W. (1986). "Self-Reports in Organizational Research: Problems and Prospects,” Journal of Management 12, 531-544.

Porter, M. E., and V. E. Millar (1985). ”How Information Gives You Competitive Advantage,” Harvard Business Review 63, 149-160.

Powell, T.C., and A. Dent-Micallef (1997). “Information Technology as Competitive Advantage: The Role of Human, Business, and Technology Resources,” Strategic Management Journal 18, 375-405.

Ravichandran, T., and C. Lertwongsatien (2005). “Effect of Information Systems Resources and Capabilities on Firm Performance: A Resource-Based Perspective,” Journal of Management Information Systems 21, 237-276.

Ray, G., W. A. Muhanna, and J. B. Barney. (2005). “Information Technology and the Performance of the Customer Service Process: A Resource-Based Analysis,” MIS Quarterly 29, 625-651.

Salant, P., and D. A. Dillman (1994). How to Conduct Your Own Survey. Chichester: Wiley.

Sangho, L., and S. H. Kim (2006). “A Lag Effect of IT Investment on Firm Performance,” Information Resources Management Journal 19, 43-69.

Sakaguchi, T., and C. Dibrell (1998). "Measurement of the Intensity of Global Information Technology Usage: Quantitizing the Value of a Firm's Information Technology,” Industrial Management and Data Systems 98, 380-394. 
Sakaguchi, T., S. Nicovich, and C. Dibrell (2004). "Empirical Evaluation of an Integrated Supply Chain Model for Small and Medium Sized Firms,” Information Resources Management Journal, 17 (3): 1-19.

Sambamurthy, V., A. Bharadwaj, and V. Grover (2003). "Shaping Agility Through Digital Options: Reconceptualizing the Role of Information Technology in Contemporary Firms,” MIS Quarterly 27(2), 237-263.

Slevin, D. P., and J. G. Covin (1990). “Juggling Entrepreneurial Style and Organizational Structure - How to get your Act Together,” Sloan Management Review 31(2), 43-54.

Small Business Administration (SBA) (2004). The Small Business Economy: A Report To The President On Small Firms Prepared By The U.S. Small Business Administration's Office Of Advocacy. Washington: United States Government Printing Office.

Steiger, J. H., and J. C. Lind (1980). "Statistically Based Tests of the Number of Common Factors,” paper presented at the annual meeting of the Psychometric Society, Iowa City (Spring).

Tanabe, K., and C. Watanbe (2005). "Sources of Small and Medium Enterprises Excellent Business Performance in a Service Orientated Economy,” Journal of Services Research 5(1), 5-20.

Teece, D., G. Pisano, and A. Schuen (2000). "Dynamic Capabilities and Strategic Management,” Nature and Dynamics of Organizational Capabilities, 334-363.

Tippins, M. J., and R. Soh (2003). "IT Competency and Firm Performance: Is Organizational Learning a Missing Link?” Strategic Management Journal 24, 247-252. 
Trott, P., and A. Hoecht (2004). "Enterprise Resource Planning and the Price of Efficiency: The Trade Off Between Business Efficiency and the Innovative Capability of Firms,” Technology Analysis \& Strategic Management 16, 367-379.

Verbees, J. H. M., and M. T. G. Meulenberg (2004). 'Market Orientation, Innovativeness, Product Innovation, and Performance in Small Firms,” Journal of Small Business Management 42(2), 134-154.

Vermeulen, P. A. M. (2005). “Uncovering Barriers to Complex Incremental Product Innovation in Small and Medium-Sized Financial Services Firms,” Journal of Small Business Management 43(4), 432-452.

Walker, R. M. (2005). "Innovation and Organizational Performance: A Critical Review of the Evidence and a Research Agenda,” Academy of Management Conference Best Paper.

Wilcock, L. P. and S. Lester (1997). "In Search of Information Productivity: Assessment Issues,” Journal of Operational Research Society 48(11), 1082-1094.

Wolff, J. A., and T. L. Pett (2006). "Small-Firm Performance: Modeling the Role of Product and Process Improvements,” Journal of Small Business Management 44(2), 268-284.

Xiang, D. C., and S. F. Lan (2001). "IT Adoption in Manufacturing Industries: Differences by Company Size and Industrial Sectors - The Case of Chinese Mechanical Industries,” Technovation 21(11), 649-660.

Zahra, S (1993). “New Product Innovation in Established Companies: Associations with Industry and Strategy Variables,” Entrepreneurship Theory and Practice 18(2), 47-69.

Zahra, S. A., Neubaum, D. O., and B. Larraneta (forthcoming), “Knowledge Sharing and Technological Capabilities: The Moderating Role of Family Involvement,” Journal of Business Research. 
Zirger, B. J., and M. A. Maidique (1990). “A Model of New Product Development: An Empirical Test,” Management Science 36, 867-883. 
Figure 1: Conceptual Model

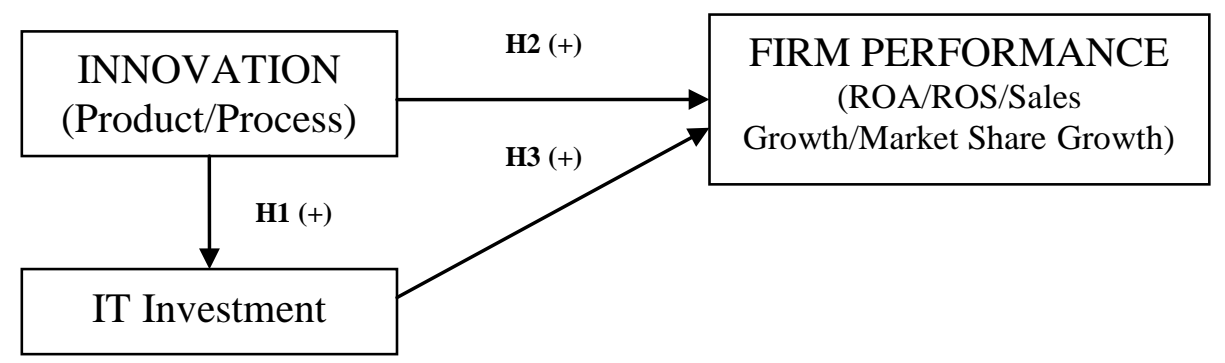


TABLE 1

\begin{tabular}{|c|c|c|c|c|c|c|}
\hline \multicolumn{7}{|c|}{ Descriptives, Coefficient Alphas, and Correlation Matrix } \\
\hline Latent Construct & Mean $^{1}$ & S.D. & $\begin{array}{l}\text { Coefficient } \\
\text { Alpha }\end{array}$ & 1 & 2 & 3 \\
\hline 1. Product Innovation & 2.90 & .97 & .78 & & & \\
\hline 2. Process Innovation & 2.70 & .89 & .69 & $.31^{* *}$ & & \\
\hline 3. IT Investment & 2.85 & 1.04 & .88 & $.29 * *$ & $.22 * *$ & \\
\hline $\begin{array}{l}\text { 4. Firm Performance } \\
k^{*} p<.01 \text { (2-tailed) }\end{array}$ & 3.32 & .96 & .88 & $.20 * *$ & $.19 * *$ & $.48^{* *}$ \\
\hline
\end{tabular}

\footnotetext{
${ }^{1}$ The measures were summated and then divided by the number of items for each respective measure.
} 
TABLE 2

Structural Model Parameter Estimates and

Goodness-of-Fit Statistics for Hypothesized Model $(\mathrm{n}=311)^{2}$

Estimates and

Standardized

$t-$

Fit Statistics

Estimate

Value

Gamma Parameters

Product Innovation $\rightarrow$ Information Technology

$.27 *$

4.18

Process Innovation $\rightarrow$ Information Technology

$.20 *$

2.96

Product Innovation $\rightarrow$ Performance

.02

.37

Process Innovation $\rightarrow$ Performance

.04

.62

Beta Parameter

Information Technology $\rightarrow$ Performance

$.59 *$

Theta-Epsilon Parameters $^{3}$

Return on Assets $\leftrightarrow$ Return on Sales

Sales Growth $\leftrightarrow$ Market Share Growth

$.15^{*}$

2.53

Value of IT Assets $\leftrightarrow$ Total IT Investment

$.15^{*}$

Producing Specialty Products $\leftrightarrow$ Invest in R\&D

$.17^{*}$

Model Fit Statistics:

$\chi 2=123.40$ (d.f. $=81, p<0.05$ ); CFI = .99; Delta2 = .99; RNI = .99; RMSEA = .04; GFI = .95).

$p<.05$

\footnotetext{
2 Total sample size was reduced, as we employed listwise deletion.

${ }^{3}$ The errors for these individual items were allowed to correlate to improve overall model fit.
} 